\title{
Ion Exchange Extraction of Platinum(IV) and Palladium(II) from Hydrochloric Acid Solutions
}

\author{
O. N. Kononova*, E. V. Duba, N. I. Shnaider, and I. A. Pozdnyakov \\ Siberian Federal University, Svobodnyi pr. 79, Krasnoyarsk, 660041 Russia \\ *e-mail:cm2@bk.ru
}

Received January 27, 2017

\begin{abstract}
Sorption concentration of platinum(II, IV) and palladium(II) from freshly prepared and aged two-yearold hydrochloric acid solutions by a series of anion exchangers with different functional groups and of different physical structure of Purolite and CYBBER grades was studied. The high sorption ability of the ion exchangers in relation to the extracted chlorocomplexes of noble metals is shown. It was demonstrated that palladium(II) from all tested ion exchangers can be completely desorbed with thiourea solutions acidified with hydrochloric acid, while complete desorption of platinum is achieved only from Purolite S 985 anion exchanger of the complexforming type and Purolite A 111 weak base anion exchanger.
\end{abstract}

DOI: $10.1134 / \mathrm{S} 1070427217080080$ 